\title{
KREATIVITAS IN HOUSE ADVERTISING DALAM MERANCANG DESAIN KEMASAN PRODUK
}

\author{
Pujiyanto \\ Universitas Negeri Malang (UM)
}

\begin{abstract}
Abstrak: Pada penelitian ini dibatasi pada in house advertising PT Air Mancur dalam merancang desain kemasan produk "Madurasa". In house advertising merupakan bagian kreatif yang berada dalam perusahaan besar dan dikendalikan oleh perusahaan tersebut. Sebagai contoh in house advertising di bawah departemen pemasaran PT Air Mancur yang diberi kepercayaan mendesain berbagai media promosi termasuk desain kemasan produk madu merek "Madurasa". Apakah karya desain kemasan yang dirancang sudah termasuk kreatif. Jawabannya perlu adanya penelitian lapangan melalui observasi langsung pada in house advertising PT Air Mancur, survey dengan cara melakukan angket 100 kepada penjual dan pengguna "Madurasa" se eks Karesidenan Surakarta, serta didukung dengan data kepustakaan. Data dari tiga sumber tersebut dianalisis menggunakan teori dari Doyle Dane Bernbach (DDB) bahwa kreatif merupakan penggabungan dari Relevant, Original, dan Impact. Hasil penelitian ini menunjukkan bahwa in house advertising dalam mendesain kemasan relevan sesuai dengan fungsi, memiliki sesuatu yang baru, dan berdampak positif pada konsumen, bisnis, serta sosial budaya.
\end{abstract}

Kata kunci: in house advertising, kreatif, desain, kemasan produk

\begin{abstract}
In this research is limited to PT Air Mancur in house advertising in designing product packaging design "Madurasa". In house advertising is a creative part that are in great company and controlled by the company. For example, in house advertising under the marketing department PT Air Mancur in house advertising who was entrusted with designing various promotional media including honey product packaging design brand "Madurasa". Is designed packaging design work has included creative. The answer is need for field research through direct observation on the PT Air Mancur in house advertising, the survey by conducting a questionnaire of 100 to sellers and users "Madurasa" former Surakarta, and supported with literature data. Data from three sources were analyzed using the theory of Doyle Dane Bernbach (DDB) that said creative consists of ROI, that is relevant, original, and impact. The results of this study indicate that packaging design by in house advertising has a relevant function, has something novelty and positive impact on consumers, businesses, and social culture.
\end{abstract}

Keywords: in house advertising, creative, design, product packaging

Penulis adalah salah satu pengajar di Desain Komunikasi Visual Jurusan Seni dan Desain Fakultas Sastra Universitas Negeri Malang (UM), email: pujiyanto.seni@gmail.com 


\section{PENDAHULUAN}

Produk tidak dapat hadir di pasaran secara baik bila tidak didampingi desain kemasan, karena fungsi kemasan, tidak hanya sebagai pembungkus, tetapi sebagai informasi produk dan sebagai media promosi suatu merek dan perusahaan. Klimchuk (2007:30-31) mengatakan, dalam desain kemasan diperlukan integrasi antara estetika desain, produk, bisnis, dan konsumen. Dalam kemasan produk pengaplikasian merek sebagai kepentingan kemitraan bisnis suatu perusahaan. Kehadiran toko-toko merangsang terwujudnya kemasan yang bagus mempunyai estetika pasar yang tinggi. Pemajangan produk melalui kemasan di toko-toko merupakan strategi pemasaran, bahwa setiap produk harus dapat melayani dan menjual dirinya sendiri, sehingga setiap produsen berusaha menciptakan desain kemasan yang menarik. Pemajangan produk tersebut tentunya tidak sendirian, tetapi berdampingan dengan beberapa produk sejenis. Hal inilah yang menjadi pertarungan produk melalui tampilan kemasan. Pertarungan ilmu merancang kemasan melalui kreativitas advertiser adalah salah satu strategi mengalahkan saingan produk lain untuk merayu pilihan konsumen. Maka dari itu, desain kemasan sebaiknya memiliki fungsi sebagai identitas produk, mengomunikasikan perbedaan produk, sebagai strategi promosi, dan sebagai cintra perusahaan.

a) Desain kemasan sebagai identitas produk. Danger (1992:97) mengatakan, bahwa desain kemasan memainkan peran sangat penting dalam identitas produk, karena kemasan sebagai penghubung antara produsen, pengecer, dan pelanggan. Kemasan produk merupakan bagian terpadu dari rencana pemasaran dan harus mencerminkan tema promosi yang ingin disampaikan, yaitu; (1) membuat daya tarik pada kemasan dan produk isinya, (2) bertindak sebagai pengikat produk, (3) menciptakan dorongan untuk membeli produk, (4) mempromosikan citra merek. 
b) Desain kemasan secara visual berfungsi untuk mengkomunikasikan perbedaan produk. Dari sudut pandang penampilan, bila tanpa desain kemasan yang berbeda akan dipandang produk sama. Menurut Klimchuk (2007:35-36) idealnya, ketika desain kemasan mampu memberikan informasi yang jelas dan spesifik kepada konsumen yang akan mendapatkan nilai poin terhadap produk pembanding, di mana satu produk tersebut tampak lebih efektif, nilainya lebih baik, dan kemasannya lebih nyaman. Konsumen dalam membeli produk kadang bukan berdasarkan kebutuhan yang digunakannya tetapi dalam membeli produk berdasarkan keinginannya karena melihat desain kemasan yang "cantik".

c) Melalui desain kemasan merupakan strategi promosi untuk menarik minat konsumen terhadap produk yang dibungkusnya. Strategi promosi melalui daya tarik konsumen melalui desain kemasan sering dilakukan oleh berbagai perusahaan besar. Strategi yang berhadapan dengan konsumen melalui desain kemasan agar mereka mengetahui produk yang akan dibeli, maka dari itu desain kemasan yang dinyatakan berhasil oleh Widiantoro (MIX, 2008:54) adalah: (1) Membuat konsumen melihat saat melewatinya. (2) Membuat konsumen berhenti dan mengambil produk tersebut. (3) Menyakinkan konsumen untuk memilih suatu merek dan tidak merek pesaing. (4) Mampu mengkomunikasikan personalitas merek dan menciptakan hubungan dengan konsumen. (5) Membangun loyalitas terhadap merek, yang tampak kelihatan cantik, mudah dikenal dan mudah digunakan. (6) Memberikan petunjuk bagi konsumen tentang bagaimana menggunakan produk tersebut. (7) Menginformasikan kepada konsumen tentang bahaya, kandungan produk, dan sebagainya. Kemenarikan sebuah desain kemasan bisa dikatakan berhasil bila konsumen tersebut kesensem pada kemasan sekaligus produknya hingga akhirnya membelinya. 
d) Desain kemasan sebagai citra perusahaan. Citra dibangun sejak perusahaan itu mulai berdiri maupun produk mulai diciptakan, berkembang, hingga akhirnya dipercaya oleh konsumen melalui desain kemasan. Tampilnya desain kemasan dapat meningkatnya kepercayaan masyarakat terhadap produk maupun merek. Kemanapun konsumen pergi, bila mereka sudah terpengaruh pada suatu produk atau merek maka mereka akan selalu mencari produk maupun merek yang disukai. Maka citra harus terbentuk dihati konsumen, sehingga terwujudnya: (1) konsumen lebih percaya diri, (2) bergaya modern, (3) adanya peningkatan prestige, dan (4) bergaya masyarakat kelas tinggi.

\section{KAJIAN TEORI}

Kreativitas artistik (artistic creativity), merupakan kreativitas yang dimiliki secara alamiah, seperti melukis, mengubah musik, mendesain, dan sebagainya. Kreativitas penemuan (creativity of discovery), merupakan penemuan teori maupun konsep baru, seperti Archimedes yang keluar dari kamar mandi sambil berteriak "eureka". Kreativitas humor (creativity of humor), merupakan memandang dunia dari sudut pandang yang berbeda untuk memunculkan kreativitas (Clegg,2001:6). Kreativitas merupakan sesuatu yang dimiliki manusia berupa kemampuan untuk menghadapi masalah untuk memecahkannya secara cepat dan akurat dengan caranya sendiri untuk menghasilkan hal-hal baru serta unik yang berbeda dan lebih baik dari sebelumnya. Kreativitas bukan sekedar keahlian, atau bakat, tetapi terkait dengan konteks, situasi dimana seseorang manangkap masalah dan melaksanakan proses kerja. Pengalaman dan familiaritas akan menjadi faktor penting dalam menentukan kreativitas dari respons kita terhadap masalah.

Orang yang memiliki daya kreativitas tinggi dapat menyajikan suatu karya yang mempunyai keindahan yang sesungguhnya. Marxis berpendapat bahwa seni/desain bukan merupakan pengumpulan ulang terhadap apa yang sudah ada, tetapi merupakan proyeksi yang simbolik yang memperhatikan masa depan dengan demikian mengungkapkan kekuatan-kekuatan kreatif umat manusia (Arvon.2010:29). Kreativitas dapat berarti proses dalam menciptakan karya 
desain, hasil akhir dari karya desain yang diciptakannya, serta nilai guna pada karya desain tersebut. Edward deBono menyebutkan sebagai "pemikiran lateral" yaitu proses mengeksplorasi hubungan-hubungan baru, memecahkan pola-pola pemikiran mapan untuk membangkitkan gagasan-gagasan baru dan melepaskan cara-cara pikiran lama. Gagasan-gagasan yang dijungkirbalikkan untuk didapatkan cara-cara baru, Lee \& Johnson (1993:173) konsep ini disebut cara berpikir "keluar dari kotak".

Salah satu yang menjadi alasan desainer dalam merancang desain kemasan adalah pesampilan fisik kemasan yang dianggap dapat menjual produk. Lalu bagaimana desainer yang kreatif memiliki nilai lebih dalam berkarya. Karya desain yang dihasilkannya memiliki kreativitas yang tinggi bila dibandingkan dengan orang lain lain. Melalui karya yang baik, bila konsumen melihatnya akan "kesensem" menggeleng-gelengkan kepala karena melihat karya desain yang hebat dan berbobot. Bila melihat karya yang mempunyai bobot kreativitas tentu desainer tersebut memiliki jiwa kreator. Dalam How Designer Think Kreativitas yang ditulis oleh Lawson (1980:156), adalah kata sarat nilai dan melambangkan penilaian mutu-tidaknya yang menamai sesuatu yang baru. Menurut agensi Doyle Dane Bernbach (DDB) New York (Moriarty, Mitchell \& Wells. 2011:433455) desain kreatif dan efektif adalah desain yang mengandung ROI: relevant (relevan), original (orisinal), dan dan memberi impact (dampak). Rumusan ini seperti cara orang bisnis berbicara secara metaforis tentang kreatifitas dari segi "return on investment". Ide yang relevan dan memiliki arti bagi masyarakat. Orisinal berarti ide yang bersifat baru, segar, tak terduga, tak lazim, mengejutkan dan menarik perhatian yang berdampak menimbulkan kesan di hati masyarakat.

\section{METODE PENELITIAN}

Pendekatan dalam penelitian ini menggunakan penelitian terarah yang memfokuskan beberapa aspek yang dipilih berdasarkan kepentingan, tujuan, dan minat yang diteliti. Penelitian ini dilakukan menggunakan prosedur metode mixing (pencampuran) yaitu pencampuran dua jenis data kuantitatif dan 
kualitatif yang dilakukam mulai tahap pengumpulan data, tahap analisis data, hingga kesimpulan. Menurut Creswell (1994:310-311) dua jenis data tersebut ditulis secara terpisah, namun secara inplisit keduanya tetap saling berhubungan satu sama lain. Data diperoleh melalui observasi, angket, dan kepustakaan.

Observasi yang digunakan dalam penelitian ini adalah observasi tak partisipan (non participant observation), yaitu pengamat berada di luar objek yang diamati dan tidak ikut dalam kegiatan-kegiatan yang mereka lakukan. Dengan demikian pengamat lebih mudah mengamati kemunculan tingkah laku yang diharapkan. Berdasarkan cara pengamatan yang dilakukan, peneliti menggunakan observasi berstruktur, menurut Soehartono (1995:69-70) yaitu memusatkan perhatian pada tingkah laku tertentu sehingga dapat dirancang apa saja yang harus diamati. Prosedur pengumpulan data dengan menggunakan angket merupakan teknik pengumpulan data dengan cara menyerahkan atau mengirimkan daftar pertanyaan untuk diisi sendiri olah responden kepada 100 penjual dan pengguna yang menyebar ke seluruh eks Karesidenan Surakarta, yaitu kota Surakarta, Sukoharjo, Klaten, Boyolali, Wonogiri, Karanganyar, dan Sragen. Dalam penelitian ini, peneliti menggunakan pertanyaan dalam angket bersifat semi terbuka, berupa option jawaban sudah tersusun, tetapi kepada responden masih diberi kesempatan untuk memberikan jawaban lain (Suyanto, 1995:70). Dalam angket ini, responden diberi jawaban lain sesuai dengan keinginan dan harus memberi alasan mengapa responden memilih jawaban tersebut. Sebagai data pendukung dilakukan pengumpulan data melalui kepustakaan berupa leteratur yang telah dicetak maupun buku on-line yang berISBN, dan jurnal ilmiah yang telah dicetak yang terakreditasi DIKTI/LIPI serta jurnal internasional terbitan on-line yang bereputasi.

Dari data-data tersebut lalu dianalisis berdasarkan teori kreativitas dari Doyle Dane Bernbach (DDB) New York yaitu desain yang kreatif dan efektif adalah karya yang relevant, original, dan memberi impact (ROI). Menurut Moriarty, Mitchell \& Wells (2009:433-455), desain yang baik adalah relevan 
(relevant) dan memiliki arti bagi khalayak. Orisinal (original) berarti ide yang bersifat baru, segar, tak terduga, tak lazim, mengejutkan dan menarik perhatian. Dampak (impact) yaitu menimbulkan nilai prositif terhadap lingkungan.

\section{HASIL DAN DISKUSI}

\section{Desain yang Relevan}

Relevan atau "sesuai", yang berarti desain kemasan yang dihasilkan in house advertising harus sesuai dengan produk dan merek. Melalui desain tersebut, calon pembeli tanpa membuka kemasan sudah mengerti isi produk didalamnya. Di samping itu, media juga bertugas sebagai informasi produk, bahwa "Madurasa" merupakan merek suatu produk yang bahan dasarnya dari madu. Produk madu secara visual ditampilkan melalui gambar lebah, madu, sarang lebah, dan pengaduk madu. Melalui berbagai gambar tersebut, khalayak sebagai pembeli atau pengguna lebih mudah mengetahui produk yang akan dibeli. Sebagai contoh "Madurasa" mempunyai berbagai rasa buah, maka dalam desain kemasan ditampilkan gambar jeruk, stroberi, anggur yang mengarah pada rasa produk, atau yang dikenal produk varian. Secara visual, gambar-gambar pada desain kemasan "Madurasa" sudah sesuai atau relevan dengan produk yang dibungkus. Gambar yang ditampilkan tertata rapi, jelas, menarik, memberi kesan adanya kesungguhan dalam memproduksi "Madurasa" produk varian. Melalui berbagai gambar pada kemasan produk tersebut minimal sebagai informasi kandungan produk yang pada "Madurasa".

Secara verbal kualitas produk "Madurasa" diinformasikan melalui "penjelasan produk", "fakta nutrisi", "berat/ukuran" dan "teks komposisi" yang tertera pada desain kemasan. Informasi verbal tentang kualitas produk tersebut ditujukan kepada konsumen agar mengetahui secara jelas tetang produk yang akan dibeli. Agar konsumen tetarik pada pesan yang disampaikan, melalui bahasa verbal maka kalimatnya bersifat membujuk, seperti melebih-lebihkan manfaat madu pada "teks pemanis". Melalui cara ini PT Air Mancur sebagai 
produsen "Madurasa" dapat bermain melalui beberapa merek sekunder yang memiliki pesan verbal yang beda.

Perusahaan yang berdiri sejak 1963 ini, mempunyai kewibawaan karena usia maupun pengalamannya. Bagi konsumen yang fanatik terhadap PT Air Mancur, mereka selalu menerima terhadap produk dan merek yang diciptakan perusahaan tersebut. Adanya kepercayaan ini, maka tiap desain kemasan selalu ada nama PT Air Mancur dalam bentuk flag ship yaitu bentuk kotak melengkung ke bawah yang berwarna kuning ditempatkan di pinggir kemasan produk "Madurasa". Melalui flag ship, para khalayak langsung mengetahui dari mana produk maupun merek tersebut berasal. Hadirnya flag ship di setiap desain kemasan "Madurasa" merupakan teriakan berkali-kali sebagai strategi promosi. Menurut Djayakusumah (1982:9) cara tersebut merupakan teriakan berulangulang merupakan strategi dari penjualan suatu produk, agar khalayak tidak lupa, bahwa produk tersebut berasal dari PT Air Mancur. Bila desain kemasan produk ada nama perusahaan, maka para konsumen langsung percaya. Konsumen yang fanatik mengatakan; "apapun bentuk produknya dan apapun mereknya akan selalu diterima jika ciptaan oleh PT Air Mancur".

Khalayak sebagai calon konsumen merupakan target utama dalam penjualan produk. Produk yang dipromosikan melalui desain kemasan yang baik, akan berdampak positif pada calon pembeli. Media promosi berupa kemasan yang baik adalah dapat menarik perhatian khalayak, baik unsur-unsur visual dan verbal, simbol, maupun bentuk kemasan. Pesan dalam media yang mudah diingat, maka nama merek pada kemasan produk sering ditampilkan berukuran besar dan warna yang mencolok. Agar pesan media dapat diterima oleh khalayak bentuk pesan yang relevan, khususnya produk yang diarahkan pada konsumen berdasarkan segmentasi tertentu. Desain media promosi termasuk desain kemasan yang baik menurut Moriarty, Mitchell, dan Wells (2009: 455), adalah media tersebut mendapat perhatian di tengah berjubelnya media promosi, selalu diingat, dan relevan bagi konsumen. 


\section{Desain yang Orisinal}

Orisinal adalah sesuatu yang baru, sama sekali belum ada. Berdasarkan sejarah di tahun 1984, "Madurasa" merupakan merek produk cair pertama yang diluncurkan ke pasar dalam bentuk kemasan sachet. Pada masa itu sudah ada produk lain yang sudah beredar dalam kemasan sachet, namun belum ada produk dalam bentuk cair (MIX, 2009:35-36). Cara cerdik orisinal ini diawali dari pemasaran lapangan yaitu para penjual di kios-kios maupun para penjual jamu gendong yang kerepotan menuangkan madu ke dalam gelas sebagai campuran jamu. Melalui kemasan sachet inilah "Madurasa" sebagai jenderal di antara kompetitor produk madu. Desain yang sederhana dan komunikatif sehingga "Madurasa" mudah dikenal masyarakat, yang akhirnya ditiru oleh perusahaan lain. Meskipun ada beberapa kompetitor, "Madurasa" tetap yang terdepan karena yang pertama, seperti yang dikatakan oleh Smiers (tt: 349) dalam Art Under Pressure ditegaskan bahwa desain memang gampang diduplikat dan ditiru, meskipun demikian advertiser tetap dapat menikmati keunggulan kompetitifnya karena dia adalah yang pertama memasarkan produk melalui desain kemasan sachet (gambar 1).

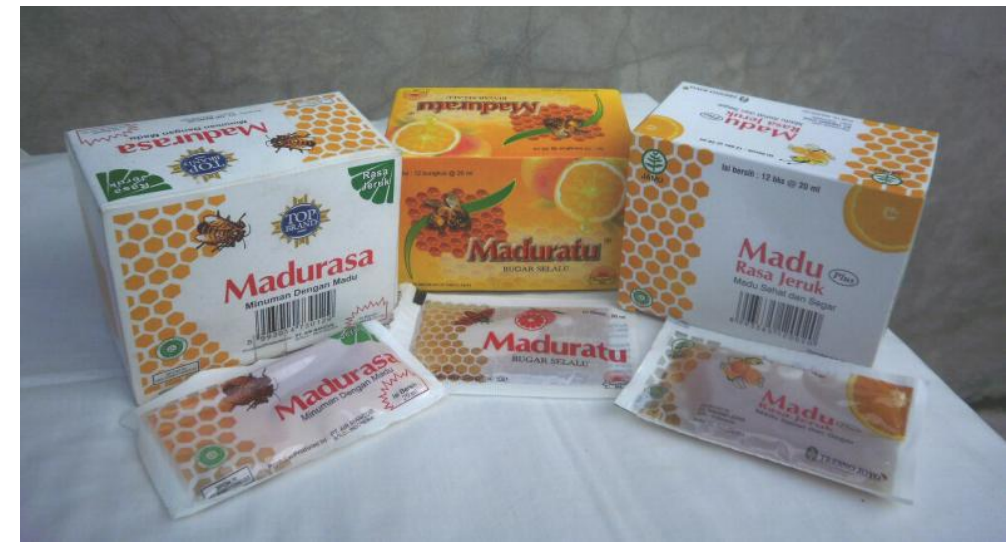

Gambar 1 "Madurasa" diantara merek "Maduratu" dan "Madu plus"

"Madurasa" telah dikenal sebagian besar masyarakat Jawa. Agar tetap terjaga namanya, maka merek tersebut dikembangkan menjadi merek-merek sekunder. Melalui merek-merek sekunder terciptalah desain kemasan yang 
berbeda-beda sesuai dengan karakter produk maupun merek tersebut. Dalam mendesain kemasan, advertiser terlebih dulu melakukan pengamatan lapangan hingga terciptalah bentuk kemasan produk dan desain periklanan. Dalam mendesain kemasan produk menurut in house advertiser Eko Bambang, diawali pengamatan pasar tentang desain yang telah ada. Melalui pengamatan desain kemasan yang telah ada di pasaran, akan lebih cepat menggali ide dalam penciptaan desain kemasan produk. Hal ini dipertegas oleh Kelley dan Littman (2001:88) dalam The Art Innovation, menggaris bawahi bahwa inovasi yang sukses menunjukan bahwa orang tidak selalu melakukan hal yang "benar" atau membuat lompatan yang diperlukan untuk menjembatani kesenjangan antara kebiasaan dan ide baru yang murni. Penggunaannya secara luas sering memerlukan waktu. Pengamatan yang pintar adalah cara untuk memperpendek siklus itu dan membuat perubahan yang dapat diterima pengguna. Melalui kemasan yang ada dipasaran tersebut lalu dirubah dan dikembangkan menjadi kemasan baru. Menurut Buzan (2001:53), dalam The Power of Creative Intelligence menyatakan bahwa neniru adalah alat esensial pertama dalam proses belajar. Inilah cara otak membangun fondasi pengetahuan. Dari pengetahuan dasar itulah seseorang dapat menambahkan kreativitas untuk dirinya.

Desain kemasan "Madurasa” merupakan redesign atau pengembangan dari desain yang telah dirancang sebelumnya di in house advertising menjadi desain baru. Redesign dilakukan melalui perubahan, pengembangan dari yang sudah ada menjadi bentuk baru hal ini termasuk kreativitas (Buzan, 2001:53). Redesign dianggap lebih mudah dan lebih cepat dalam mendesain. Desain yang sudah ada di pasaran merupakan data uji coba lapangan, adalah kemasan produk lain yang sudah berjalan dengan baik. Melalui kemasan tersebut, advertiser PT Air Mancur tinggal mendesain ulang sesuai produk merek sekunder. Pengembangan desain melalui cara ini lebih cepat diterima masyarakat. 
Kemasan primer "Madurasa" merupakan dasar dalam menciptakan desain kemasan berikutnya. Bila desain kemasan produk pertama pada merek primer mempunyai gaya desain tertentu, maka dersain kemasan pada merek sekunder mengikutinya. Antara desain kemasan merek primer dan sekunder mempunyai "desain yang sepadan" atau karakternya hampir sama seperti bentuk konvensional kesegi-empat. Bentuk ini tetap dipertahankan karena hubungannya dengan biaya produksi agar dapat ditekan dan aplikasinya dapat ditempatkan dimana saja. Supaya media konvensional tersebut tidak membosankan, maka tiap merek sekunder mempunyai desain yang beda namun tetap senafas dengan desain kemasan agar khalayak mudah mengingatnya.

In house advertising PT Air Mancur bukanlah biro advertising umum yang menangani beberapa claince untuk menciptakan merek maupun desain kemasan dari berbagai perusahaan. Beberapa biro advertising di samping melayani kemauan claince juga dapat menuangkan idenya ke dalam desain yang di ciptakan. Kreator dalam hal ini menciptakan desain kemasan mempunyai dua tujuan, yaitu karya desain yang sesuai dengan permintaan cliance dan desain yang diperuntukkan kompetisi lomba. Kompetisi lomba tingkat nasional dan internasional merupakan ajang bergengsi bagi biro advertising yang ingin mendapatkan penghargaan tersebut. Dalam kompetisi ini, segi orisionalitas menjadi tujuan utama, maka para kreator diasah idenya untuk menciptakan karya yang mumpuni. Karya desain kemasan dalam kompetisi ini sering menggunakan pendekatan "emosional" yang melebih-lebihkan produk maupun merek yang banyak konotasi. Pendekatan "emosional" sering diperuntukkan pada masyarakat berpendidikan atas maupun selera yuri kompetisi. Pendekatan ini identik dengan karya yang kreatifitasnya tinggi, disamping itu segi orisionalitasnya sangat kental. Pada ajang ini, pihak PT Air Mancur tidak pernah mengikutinya. PT Air Mancur tidak begitu merisaukan bila dianggap desain kemasan ciptaannya kurang kreatif dan tidak pernah mengikuti ajang kompetisi. Di sisi lain, melalui desain yang sederhana ini produk "Madurasa" dapat bertahan 
dan berkembang menjadi berbagai produk varian dan merek sekunder. Ini sebagai bukti bahwa kreativitas tidak hanya dilihat dari sisi desainnya saja tetapi pengaruh desain terhadap produk yang dijual.

Inhouse advertiser, bekerja mengikuti program perusahaan yang taat mengikuti perintah atasan. Para advertiser tidak di tuntut menciptakan karya "kompetisi", tetapi menciptakan pedia promosi agar produk maupun merek cepat dikenal masyarakat, dan produk terbeli. Dalam Media/Impact: An Introduction to Mass Media yang ditulis oleh Biagi (2010: 269), merujuk dari pelopor periklanan Claude Hopkins, yang menyatakan media promosi termasuk desain kemasan harus alami dan sederhana agar dapat menangkap pembeli

Madjadikara (2004:66-69), dalam bukunya Bagaimana Biro Iklan Memproduksi Iklan dinyatakan bahwa strategi kreatif itu pada dasarnya merupakan upaya atau cara untuk menjual. Konsep kreatif harus relevan dengan produknya, harus membuat orang mengerti ada sebenarnya maksud pesan pada dersain kemasan. Tuntutan inilah desain kemasan harus diarahkan pada target konsumen, maka in house advertiser dalam mencipta desain sangat hati-hati. Agar desain yang diciptakannya sampai pada konsumen, maka dalam penataan unsur-unsur desain mengarah keseimbangan formal yang, enak dilihat dan enak dibaca, sehinga calon konsumen dapat memahami selanjutnya melakukan tindakan. Berdasarkan target khalayak tersebut, desain media promosi yang diciptakan menggunakan pendekatan rasional, apa adanya sesuai kondisi produk. la hanya berpikir bagaimana desain kemasan yang diciptakan dapat menjual produk yang dipromosikan. Dalam Confesions of an Advertising yang ditulis Ogilvy (1987:123), bahwa media promosi yang baik adalah media promosi yang disetujui oleh pelanggan dan menjual produk tanpa menarik perhatian pada dirinya sendiri.

\section{Desain yang Mempunyai Dampak}

Dampak dalam desain kemasan merupakan pengaruh pada pesan yang disampaikan terhadap konsumen selaku penerima pesan. Desain kemasan yang baik adalah terjadinya dampak terhadap penerima pesan (konsumen) sehingga mereka melakukan tindakan pembelian. Dampak positif tersebut dapat 
ditimbulkan melalui desain kemasan, baik kesan visual maupun verbal. Biagi (2010), menyatakan bahwa media dapat berdampak pada (a) kepercayaan konsumen, bagaimana orang akan bertindak selalu mengikuti pesan media, (b) bisnis, bagaimana pengaruh media terhadap perkembangan bisnis perusahaan, (c) sosial budaya, bagaimana konsumen tertarik pada produk maupun merek baru yang dipromosikan pada desain kemasan.

\section{a) Dampak Desain pada Kepercayaan Konsumen}

Pesan melalui gambar dapat menarik perhatian khalayak tanpa dibatasi umur. Anak-anak yang belum dapat membaca, mereka cepat menangkap pesan yang disampaikan melalui gambar. Melalui bahasa visual berupa gambar, ia sudah hafal produk varian "Madurasa". Melalui gambar, pesan mudah dimengerti apa isi dalam kemasan seperti rasa produk atau produk varian. Masyarakat umum tertarik pada "Madurasa" karena gambar lebah dan madunya. Dari hasil angket terbukti bahwa $71 \%$ dari 20 penjual di kios-kios, dan 64\% dari 50 pengguna sangat tertarik pada gambar tersebut, karena ditampilkan sangat jelas, mudah dimengerti, dan mengena pada produk yang berasal dari bahan dasar madu.

Unsur desain yang cepat dilihat oleh masyarakat, adalah warna. Warna dalam desain kemasan biasanya diarahkan pada institusi perusahaan maupun merek produk. PT Air Mancur yang dominan warna kuning dan warna merah yang selalu hadir diberbagai media promosi. Kedua warna ini dipertahankan sebagai ciri khas perusahaan. PT Air Mancur merupakan perusahaan besar yang banyak pengalamannya salah satunya dalam memproduksi "Madurasa", yang selalu diingat karena desain kemasan yang menarik. Seperti yang dinyatakan oleh Kotler (2003:57) dalam Marketing Insights $A$ to $Z$, bahwa desain yang baik memerlukan pemikiran yang mendalam terhadap semua kegiatan yang dilakukan

oleh pelanggan pada saat mereka membeli, menggunakan, dan membuang produk tersebut. Melalui media promosi yang baik, PT Air Mancur akan selalu diingat oleh para konsumen. Fanatikisme pelanggan PT Air Mancur disebabkan 
karena perusahaan tersebut menjadi image positif melalui desain kemasan yang diciptakannya. Apapun produk atau merek yang dilakukan PT Air Mancur selalu dinilai bagus. Begitu juga merek "Madurasa", meskipun berkembang menjadi beberapa merek sekunder, mereka menganggap tetap sama kualitasnya. Di samping itu, nama merek ini juga mudah dihafal dan sudah lama dikenal, seperti pendapat penjual di kios jamu dan pengguna sebanyak 63\% dari 65 responden di tujuh kota/kabupaten di daerah eks Karesidenan Surakarta sudah hafal nama merek "Madurasa".

Bagi konsumen yang ingin mengetahui tentang produk maupun merek baru, maka tugas bahasa verballah yang menjelaskannya. Untuk mengetahui kelebihan produk maupun merek, maka khalayak harus membaca penjelasan produk pada kemasananya seperti "penjelasan produk", "fakta nutrisi", "berat/ukuran" dan "teks komposisi". Bagi konsumen baru, keterangan tentang produk tersebut sangat diperlukan sebagai bandingan dengan produk lain (kompetitor) maupun produk yang dibutuhkan. Melalui informasi ini konsumen merasa tenang dalam mengkonsumsi "Madurasa" dengan harapan dapat meningkatkan kesehatan.

b) Dampak Desain pada Bisnis Perusahaan

Secara internal, desain kemasan dapat berdampak bisnis bagi PT Air Mancur. Hadirnya berbagai desain kemasan produk berdasarkan merek-merek baru menunjukkan adanya peningkatan dan perkembangan perusahaan. Perusahaan herbal jarang dapat bertahan, apalagi berkembang menciptakan berbagai produk varian. Melalui media inilah perusahaan dapat dipercaya masyarakat dan menjadikan kewibawaan PT Air Mancur di mata kompetitor. Melalui desain kemasan menjadi merek "Madurasa" dapat disegani oleh merek kompetitor dan merek yang selalu diingat masyarakat bila akan membeli madu. Tidak mengherankan hingga tahun 2009-2011 "Madurasa" mendapatkan "Top Brand" hingga tiga kali. Produk primadona di PT Air Mancur inilah yang dapat menghidupi produk lain yang kurang laku. Berkat promosi melalui desain 
kemasan, merek "Madurasa" sangat laku di pasaran sehingga perusahaan menciptakan "madurasa-madurasa baru". Semua itu berkat pesan pada desain kemasan yang membuat image merek ini selalu dihati masyarakat.

Masyarakat sudah percaya terhadap "Madurasa" karena kualitasnya. Adanya kepercayaan ini pihak PT Air Mancur selalu meningkatkan produksinya karena permintaan para penjual dan pengguna. Adanya kelompok masyarakat yang loyal terhadap "Madurasa" sangat menguntungkan pihak PT Air Mancur. Hal ini terbukti masih bertahannya "Madurasa" yang pertama dalam bentuk sachet warna putih tahun 1984. Adanya kepercayaan masyarakat ini PT Air Mancur terus mengembangkan "Madurasa" kearah produk varian dan merek sekunder, seperti, "Madurasa Premium" (tahun 2000), "Madurasa Murni" (tahun 2000), “Madurasa Klengkeng" (tahun 2000), "Madurasa Stick" (tahun 2004), “Madurasa Curcuma” (tahun 2004), “Madurasa Green Tea” (tahun 2009), dan “Madurasa Lemon Tea” (tahun 2009), seperti pada gambar 2.

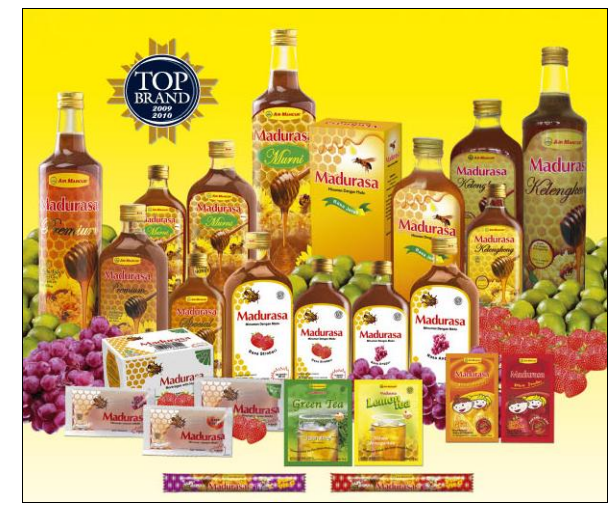

Gambar 2 “Madurasa” yang berkembang menjadi produk varian dan merek sekunder

c) Dampak Desain pada Sosial Budaya Konsumen

Desain kemasan yang diciptakan PT Air Mancur tidak hanya menawarkan produk dan merek, tetapi juga mengajak masyarakat minum madu. Budaya minum jamu selalu disampaikan pada keterangan "tek romantik" pada desain kemasan. Melalui informasi ini khususnya para konsumen baru diajak minum madu. Gejala sosial konsumen yang dulunya tidak minum madu menjadi peminum madu, yang dulunya belum mengkonsumsi "Madurasa" menjadi 
konsumen sejati. Mengkonsumsi "Madurasa" mendapat digunakan sesuai kebutuhan, seperti dapat diminum langsung untuk kesehatan, dapat juga dimanfaatkan sebagai campuran makanan dan minuman. Bagi anak-anak yang sulit makan, peran "Madurasa" sangat menentukan, karena dapat digunakan sebagai campuran dalam membuat sehingga akan beda kelezatannya. Begitu juga minuman dicampur dengan "Madurasa" akan bertambah segar, seperti jus, es, dan minuman lainnya. Sebagai orang tua yang mengetahui manfaat madu, maka makanan dan minuman selalu diberi madu agar lebih lezat, nikmat, dan berkhasiat.

Bagi masyarakat yang mengetahui manfaat madu untuk kesehatan, maka mereka selalu mengkonsumsi setiap hari. Mereka memahami, bahwa madu dapat menyembuhkan berbagai penyakit, menyehatkan badan, dan dapat beraktifitas lebih optimal. Budaya sehat inilah diinformasikan melalui slogan "Madurasa" berbunyi "sehat setiap hari" dengan harapan agar konsumen selalu minum madu. Melalui desain kemasan, produk maupun merek "Madurasa" makin dikenal masyarakat, maka tugas media tersebut adalah bagaimana agar "Madurasa" tetap di hati para konsumen, seperti pernyataan Biagi (2010:272) menyatakan ujian akhir dari setiap produk adalah pasar dan desain kemasan yang dapat merangsang konsumen untuk mencoba produk baru atau merek baru, tetapi konsumen tidak akan terus membeli produk yang tidak memuaskan.

\section{KESIMPULAN}

In house advertising berbeda dengan biro advertising. In house advertising dalam melakukan pekerjaannya berdasarkan perintah atasan di dalam perusahaan, tetapi biro advertising berkerja berdasarkan clience yang memesannya. Kreativitas in house advertising dalam merancang desain kemasan "Madurasa" didasari permintaan pimpinan jikalau ada produk-produk varian dan beberapa merek sekunder baru. Melalui desain kemasan yang baik akan memberikan kepercayaan diri terhadap produk "Madurasa" dapat dilihat dan dibaca jenis dan karakter produk yang ada di dalamnya. Maka dari itu perlunya 
desain kemasan yang dirancang secara kreatif mengarah pada segi fungsi sesuai target market. Kreativitas dalam merancang desain kemasan tidak hanya sebagai "baju" atau pembungkus produk tetapi dapat ditinjau berdasarkan relevant, original, dan impact, karena desain kemasan merupakan salah satu media promosi yang dekat dengan konsumen bila mereka akan mengonsumsi.

\section{PERNYATAAN PENGHARGAAN}

Selesainya penelitian ini berkat dukungan dan bantuan dari beberapa nara sumber, maka pada kesempatan ini penulis sampaikan terimakasih dan penghargaan yang tinggi kepada Drs. Ahmad Adib, M.Hum, PhD selaku direktur Lestudy: Center of Design Studies Surakarta telah memberi masukan tentang desain kemasan "Madurasa" dari sudat pandang akademisi. DrH. Retno Hernayati selaku manager Quality Control yang merangkap kepala perpustakaan PT Air Mancur yang membantu mencari berbegai reverensi di perpustakaan tersebut, Ir. Budi Rahayu selaku Product Manager yang telah memberi informasi tentang produk "Madurasa", Drs. Eko Bambang Widjanarko selaku Creative Design dan Agatha Tri Handayani S.Sn selaku Staff Design in house advertising, Sri Sayekti selaku peracik jamu dan pembina depot PT Air Mancur yang telah membantu pengedaran angket, serta kepada seluruh penjual dan pembeli di wilayah Kota Surakarta, Kabupaten Karanganyar, Kabupaten Sragen, Kabupaten Wonogiri, Kabupaten Sukoharjo, Kabupaten Klaten, dan Kabupaten Boyolali yang telah mengisi angket hingga terwujudnya artikel ilmian ini. Semoga semua bantuan tulus mereka dapat memberikan kesejukan dan pengembangan keilmuan di masyarakat khususnya akademisi.

\section{DAFTAR PUSTAKA}

Arvon, Henri. 1970. Marxist Esthetics. terjemahan Ikramullah. 2010, Yogyakarta: Resist Book. 
Biagi, Shierly. 2010. Media/Impact: An Introduction to Mass Media atau Media/Impact: Pengantar Media Massa. terjemahan Mochammad Irfan dan Wulung Wira Mahendra. 2010. Jakarta: Salemba Humanika.

Buzan, Tony. 2001. The Power of Creative Intelligence atau Sepuluh Cara Jadi Orang yang Jenius Kreatif terjemahan Susi Purwoko. 2004. Jakarta: PT Gramedia Pustaka Utama.

Clegg, Brian\& Paul Birch. 2001. Instant Creativity. Jakarta: Erlangga

Creswell, John W., 1994. Research Design: Qualitative\& Quantitative Approaches. London: Sage Publication.

Danger, EP. tt. Selecting Colour for Packaging atau Memilih Warna Kemasan. terjemahan Darwis Ishak. 1992. Jakarta: PT Pustaka Binaman Pressindo.

Kelley, Tom \& Janathan Littman. 2001. The Art Innovation atau The Art Innovation: Pembelajaran Kreativitas dari Ideo. Perusahaan Desain terkemuka di Amerika. terjemahan Paulus Herlambang. 2002. Jakarta: Gramedia.

Klimchuk, Marianne Rosner \& Sandra A. Krasovec. 2006. Packaging Design: Successful Product Branding from Concept to Shelf atau Desain Kemasan: Prencanaan Merek Produk yang Berhasil Mulai dari Konsep sampai Penjualan. terjemahan Bob Sabran. 2007. Jakarta: Erlangga.

Lawson, Bryan. 1980. Bagaimana Cara Berpikir Desainer. terjemahan Harfitah Widiawati. 2007. Yogyakarta: Jalasutra.

Lee, Monle \& Carla Johnson. 1999. Principles of Advertising: A Global Persfective atau Prinsip-prinsip Pokok Periklanan dalam Perspektif Global. terjemahan Haris Munandar \& Dudy Priyatna. 2009. Jakarta: Prenada Media Group.

Madjadikara, Agus S., 2004. Bagaimana Biro Iklan Memproduksi Iklan. Jakarta: Gramedia Pustaka Utama. 
MIX. 2009, The Era of Brand in Hand Marketing. Jakarta: Marketing Xtra. (12/VI/9 Februari-28 Februari 2009).

Moriarty, Sandra, Nancy Mitohell \& William Wells. 2009. Advertising. terjemahan Tri Wibowo. 2011. Jakarta: Kencana.

Ogilvy, David. 1987. Confesions of an Advertising Man atau Pengakuan Orang Iklan, terjemahan Dian Pratiwi. 1987. Jakarta: PustakaTangga.

Smiers, Joost. tt. Art Under Pressure, terjemahan Umi Haryati. 2009. Yogyakarta: Insist Press.

Suyanto, Bambang, ed. 1995. Metode Penelitian Sosial, Surabaya: Airlangga University Press.

Widiantoro. 2008. Indonesia Best Packaging 2008. Jakarta: Marketing Xtra. (Edisi 09/V/15). 